\title{
Master Questions, Student Questions, and Genuine Questions: A Performative Analysis of Questions in Chan Encounter Dialogues
}

\author{
Nathan Eric Dickman \\ Department of Religion and Philosophy, Center for Appalachian Studies and Community Engagement, Young \\ Harris College, Young Harris, GA 30582, USA; nedickman@yhc.edu
}

Received: 31 December 2019; Accepted: 4 February 2020; Published: 5 February 2020

\begin{abstract}
I want to know whether Chan masters and students depicted in classical Chan transmission literature can be interpreted as asking open (or what I will call "genuine") questions. My task is significant because asking genuine questions appears to be a decisive factor in ascertaining whether these figures represent models for dialogue-the kind of dialogue championed in democratic society and valued by promoters of interreligious exchange. My study also contributes to a more comprehensive understanding of early Chan not only by detailing contrasts between contemporary interests and classical Chan, but more importantly by paying greater attention to the role language and rhetoric play in classical Chan. What roles do questions play in Chan encounter dialogues, and are any of the questions genuine? Is there anything about the conventions of the genre that keeps readers from interpreting some questions in this way? To address these topics, I will proceed as follows. First, on a global level and for critical-historical context, I survey Chan transmission literature of the Song dynasty in which encounter dialogues appear, and their role in developments of Chan/Zen traditions. Second, I zoom in on structural elements of encounter dialogues in particular as a genre. Third, aligning with the trajectory of performative analyses of Chan literature called for by Sharf and Faure, I turn to develop and criticize a performative model of questions from resources in recent analytic and continental philosophy of language and I apply that model to some questions in encounter dialogue literature.
\end{abstract}

Keywords: Chan; encounter dialogues; genre; Mazu; Linji; questioning; philosophy of language

Dazhu bowed, and asked, "What is Huihai's own treasure?" The Ancestor said, "That which is asking me right now is your own treasure-perfectly complete, it lacks nothing. You are free to use it; why are you seeking outside?". (Cheng Chien 1992, pp. 69-70). ${ }^{1}$

Given Mazu's (709-788) apparent discouragement to seek answers to questions, at least not from masters who would seem to know the answers, it may strike some readers as misguided to seek further clarification about acts of questioning generally and the kinds of questions depicted in Chan encounter dialogue literature in particular. To do so would seem to betray a lack of understanding Mazu's point. Yet what better setting is there in which to clarify questioning than in the study of Chan literature with its preponderance of questions?

1 Jia believes that this particular encounter dialogue is probably historically authentic, given a number of connections none the least of which is Dazhu's treatise, The Teaching of Instantaneous Awakening (see Jia 2006; Hui Hai 2015). Throughout I will be replacing all Wade-Giles romanization in original sources with pinyin without setting off these changes in brackets to increase readability for non-specialists. 
I want to know whether Chan masters and students depicted in classical Chan transmission literature can be interpreted as asking open (or what I will call "genuine") questions. My task is significant because asking genuine questions appears to be the decisive factor in ascertaining whether these figures represent models for dialogue-the kind of dialogue championed in democratic society and valued by promoters of interreligious exchange. My study also contributes to a more comprehensive understanding of early Chan (ca. 700-900) $)^{2}$ not only by detailing contrasts between contemporary interests and classical Chan, but more importantly by paying greater attention to the role language and rhetoric play in classical Chan-which is not an era but a genre of Chan literature. ${ }^{3}$

What roles do questions play in Chan encounter dialogues, and are any of the questions genuine? Is there anything about the conventions of the genre that prevents interpreting the questions in this way? In order to address these topics, I will proceed as follows. First, on a global level, I survey Chan transmission literature of the Song dynasty in which encounter dialogues appear, and its role in developments of Chan/Zen traditions. Second, I zoom in on structural elements of encounter dialogues in particular. Third, aligning with the trajectory of performative analyses of Chan literature called for by Sharf (see Sharf 1995) and Faure (see Faure 1993), I turn to develop a performative model of questions from resources in recent analytic and continental philosophy of language and I apply that model to the questions in encounter dialogue literature. By laying out all these interpretive constraints to prevent reader caprice and projection, I look for leverage to speculate on the possibility of masters asking genuine questions sometimes. I intend this less as an assertive conclusion and more as a suggestive possibility.

\section{Elements of Form and Function of Chan Transmission Literature}

In this section, I provide an overview of both the basic structure of Chan transmission literature and its life in Chan/Zen traditions, as characterized in recent Western scholarship. I conclude this section by calling into question rigid dualities of "written" discourse and "spoken" discourse.

\subsection{Chan Transmission Literature}

Two representative texts of Chan transmission literature are the Zutang ji ("Anthology of the Patriarchal Hall"), compiled by 952, and the Jingde chuandeng $l u$ ("Record of the Transmission of the Lamp [from the] Jingde [Imperial period of the Northern Song]"), presented to the Song court in 1004. These texts purport to be yulu ("discourse records") of eighth and ninth century Chan masters and their interactions with students, but they differ in how they present the material. The Zutang $j i$ provides little to no contextual information surrounding master-student interactions, whereas the Jingde chuandeng $l u$ often provides a situation preceding as well as following their interactions (see Wright 1998, p. 110). Yet however much these texts might appear as if they are accurate records of originally spontaneous oral interactions, the basic problem with this literary veneer is the fact that they were not completed until over a century after the Tang dynasty (618-907) Chan masters flourished. In other words, however much the works bear marks of orality and realism, they are texts and must be approached as literary constructions rather than accurate historical records (see Faure 1986, and Berling 1987). This problematic rhetoric of "records" of spoken discourse is compacted by the texts' historical inaccuracy. For example, in the Jingde chuandeng $l u$, Bodhidharma leads a sect of Chan that did not come into being until centuries after his lifetime, and the ancient Buddhas are depicted as speaking in Chan riddles (see Wright 1998, p. 110). It appears that the editorial criteria for inclusion of material was not so much a matter of capturing the past as it actually occurred as much as a matter

2 I take this dating from McRae (McRae 2003, p. 16). Throughout, I will use "early Chan" to refer to a chronological period in which Mazu lived, but I will use "classical Chan" to refer tof a genre of literature that settled into a genre during the Song Dynasty (960-1279) whose content concerns figures purported to have lived and taught during the early Chan period.

3 Wright calls for paying greater attention to Chan language and rhetoric (Wright 1993). 
of how effective a story was for the purpose of transmitting a Dharma to future generations. Unlike modern historiographic principles, anachronism was not considered a transgression of the process of "recording." We can claim with Yanagida, then, that Chan transmission literature presupposes an orientation to history significantly differing from modern historians who presently study it (see Yanagida 1983; Wright 1992a). Given both textuality and inaccuracy of the records, it is reasonable to consider the image of Tang masters presented in transmission literature to be a construction of Chan imagination in the Song dynasty (see Faure 1986). That is, early Chan (ca. 700-900) as an historical era needs to be kept distinct from classical Chan as a genre of literature created during the Song concerning early masters.

Transmission literature is a religious genre marked by, among other things, three features: narrativity, genealogy, and presentation of a master prototype. The narrative structure of the texts, and of the Jingde chuandeng $l u$ in particular, is two tiered. On the one hand, the texts tell a story of a tradition as a whole by sequentially chronicling different individuals' enlightenments. On the other hand, they often provide biographical narratives of individual masters from birth to death. While there is no theoretical reflection on meanings of the narratives in the texts themselves, they provide significant detail on the level of individual biography (Wright 1998, p. 106). Between the events of a Chan master's birth and death, biographic details consist of stories presenting specific moments that were and are read as manifesting a power and depth of that master's awakened state. However, these specific moments are not always isolated events; they sometimes occur against the backdrop of a life narrative as well as a tradition narrative of accumulative collective enlightenment.

Such episodes often display masters in search of an heir to carry on their Dharma transmission lineage. Thus, the texts compliment as well as legitimize transmission genealogies. As Faure writes, "[Chan texts] played a crucial role in a ritual of transmission by legitimizing the patriarchal lineage" (Faure 1993, p. 229). The Jingde chuandeng $l u$, then, can be considered a family history, especially given the employment of family lineage terms such as xiongdi ("brother"), shu ("uncle"), and $z u$ ("grandfather") to symbolize and describe the relationships among the members of the tradition (see Wright 1998, p. 107). As Schlütter explains, "This principle of organization was recognized by the Song state and reflected in sources such as the Tiaofa shilei, in which regulations for monastics and monasteries were placed in the 'Household and Marriage' (huhun) category" (Schlütter 2008, pp. 83-84). The term zong ("ancestor") in particular carried pre-Buddhist connotations, which indicates, as Wright states, "knowing what it meant to belong to the [Chan] institution entailed knowing from whom it had been inherited, a historical knowledge transmitted and inculcated by means of narratives like the Jingde chuandeng $l u^{\prime \prime}$ (Wright 1998, p. 107). As with any genealogy, determining one's position in the lineage locates one with regard to both the past and the future. The transmission literature situates a purportedly ahistorical concept of enlightenment within structures of a narrative history and a genealogy in such a way that, as seems reasonable to claim with Wright, belonging to the Chan family serves as a condition of the very possibility of enlightenment (see Wright 1992a, p. 41).

The genre's conventions force readers to interpret whatever a master does or says as a presentation of awakened enlightenment (see Foulk 2000, p. 40). In classical Chan philosophy, this is fundamentally the realization of inherent enlightenment, or, as Dahui (1089-1163) puts it, the "merging" of oneself with inherent enlightenment (see Schlütter 1999, p. 113). If the activity or discourse were not the presentation of such an awakened mind, then the records would not only appear arbitrary, but also odd. Without attribution to a master, the actions and words would not seem extraordinary or profound. The genre's conventions themselves call for interpretation of the masters' mundane actions and words as indirectly about ultimate truth - to such a degree that, as Foulk indicates, the more mundane the act or statement, the more profound its meaning (Foulk 2000, p. 40). Their virtuosity in ordinariness makes them extraordinary. The genre's conventions manufacture an image of Chan masters with a particular style of behavior in which they are interpreted as manifesting the Dharma through gestures such as shocking shouts and blows, as well as by means of paradoxical statements and counter-questions that 
confound their students (see McRae 2003, p. 76). As a genre, classical Chan ought not to be regarded as a historical era, but as an image of masters according to Song dynasty literati imaginaries.

Episodes in the biographic narratives depicting enlightened masters are often rhetorical occasions where the master says something assumed to manifest their awakened mind-hence the $y u$ ("discourse") of the yulu ("discourse records"). These rhetorical interactions or jiyuan wenda ("encounter dialogues") involve both a master and a student or some other foil where the master often tests the state of mind of the student, tries to solicit awakening from the student, or transmits their Dharma to the student. The term "jiyuan wenda" literally refers to "a question-and-answer [full of] karmic potentiality" (see Yanagida 1983). Can genuine and ordinary questions have explosive potential? We will return to these dialogues full of explosive potential below for closer analysis of the roles questions play in them. Before turning to that, I want to note the impact of this literature to the formation of Zen Buddhism today.

\subsection{Impact of Transmission Literature on Chan Traditions}

The transmissions depicted in this literature reflect social practices of the Song state (960-1279), which established the foundation for the development of Chan traditions. Official documentation for a master's recognition of a student's awakening developed only during this time. It came in the form of a transmission certificate, which the student only received once the student ascended to the abbacy of a public monastery (Schlütter 2008, p. 92). That is, transmission certificates accompanied assumption of institutional roles, not sheer inner experiential moments or profound recognitions between individuals. In the literature, however, the most important condition for Dharma transmission, the master's recognition, often takes form in an exchange of words. Who is this exchange of words for, since it is not a record of something that happened? In contrast to calling on historical exegetical practices oriented toward uncovering real past masters as they were recorded and preserved, this Song construction of eighth and ninth century masters is marked by a rhetorical practice oriented toward a future, particularly a future public sphere of readers and a future of subsequent generations of Chan traditions (Faure 1993, p. 147). The literature impacted both the development of Chan traditions later in the Song dynasty as well as contemporary literati readerships since Chan abbots sought patrons to support their monasteries.

Through their dissemination to reading publics and later generations of Dharma heirs by means of transmission transcription, specific rhetorical episodes supplied basic models for subsequent Chan discursive practice. Once excerpted from the broader narrative context and commented upon by a later master, specific episodes became gongan ("public cases" or "precedents"). The term gongan, its origins in medieval Chinese jurisprudence, literally refers to the table or bench (an) of a judge (gong) (Foulk 2000, p. 18). By the end of the thirteenth century, gongan were being compared to legal precedent cases, indicating their role as authoritative standards for determining and authenticating purported levels of Chan experience and spiritual attainment (Foulk 2000, p. 18). Just as with any community, the shared concerns of Chan monastics were constituted by and expressed through their shared discursive practices, practices informed by the standards of excellence represented by gongan (see Wright 1992b, p. 124). ${ }^{4}$ Dahui, in his attempt to purify Chan practice as well as solicit patronage from affluent literati, developed a method for the realization of one's inherent enlightenment through meditation on the huatou ("crucial phrase") of individual gongan (Schlütter 1999, p. 115; see also Schlütter 2000, p. 180). Reflection on huatou was central to Dahui's method of instruction aimed at producing overwhelming doubt in students, or what he called "the great ball of doubt," frustrating their discursive and grasping intellect while simultaneously preserving their investigative attitude (Schlütter 1999, p. 124; Foulk 2000, p. 22). The students' acquisition of skill to comment on huatou

4 MacIntyre elaborates on the relations between standards of excellence and practices, where role models can serve as regulative ideals (MacIntyre 1984, p. 187; see also Anderson 2001). 
spontaneously and insightfully measured the students' success in the practice (see Foulk 2000, p. 23). This is the origin of what is known as koan meditation practice, predominant in Rinzai monasteries.

The Song readers of transmission literature, and gongan transcriptions in particular, consisted mainly of elite monastics and literati. The texts circulated among readers with varying levels of interest in Chan: from Chan enthusiasts to those committed to the collection and reading of texts due to their sheer rarity. Although printed texts were available and became increasingly common, they were still rare and thus were items of consumption for the book culture of the Song. Besides the rarity of the texts, what applied to readers then also applies to readers now. The literature allows readers to enter what is often depicted as quite private situations, intimate conversations between masters and students. Moreover, the genre placates readers' egos by placing them somewhere between masters and students, where readers can identify students' delusions yet can never fully be certain of what the master means. While readers might feel superior to the students, we are also like students insofar as we are-presumably-unenlightened.

In the Song, the iconoclastic discursive practices of classical Chan masters were enshrined in textual form as icons, inaugurating a form of veneration of words and actions of "past Buddhas" - replacing rhetorical practice with hermeneutical practice (see Faure 1993, p. 148). By interpreting the literature, Chan modes of being-in-the-world became live possibilities and regulative ideals for the readers, specifically the Song literati but also today's readers. ${ }^{5}$ Training in the monastic community thus has come to require submission to literary traditions and to self-transformations that occur within Chan discursive practices. Only advanced members of the monastic community participate in the unusual and exclusive language (Wright 1992b, p. 126). Fluency in the rhetoric purports to display one's depth of experience in Chan. Thus, a crucial difference between the enlightened and the unenlightened is a discursive difference-a distinction between very different ways of participating in language (Wright 1992b, p. 132). As Hershock explains, it is about performing discursive actions with interactive and improvisational genius (Hershock 2009, p. 134).

The shift from transmission narratives to gongan and huatou meditation practices divulge an increased tendency of students to publish, and thus publicize, the words of masters despite masters' persistent warnings that the soteriological power of their words is limited to singular moments (Faure 1993, p. 231). Inscribing the discourses as if one were recording them restructures them in accord with literacy by freeing the discourses from any specific context and thus replacing direct reference in face-to-face dialogue with indirection and intratextual self-referentiality or, what Ricoeur calls, "productive reference" (see Ricoeur 1976). Such "semantic autonomy" facilitates the interpretive production of a "surplus of meaning," and one significant function of narrative texts like transmission literature of the Song is their capacity to disclose a possible form of life or way of being in the world to readers (Ricoeur 1976, p. 94).

The depiction of wenda (again, "question-and-answer") between masters and students, so central to Chan transmission literature, indicates the importance of orality to the Song imagination, an importance, Faure emphasizes, that is only enhanced by the literature (Faure 1993, p. 228). This is legitimately inferable from their dialogical structure, which also implies a dialogical and performative conception of writing and reading where just as the master seeks out an interlocutor, so also does the text seek out a reader. However, as Faure points out, this engagement has been assumed to be about uncovering a reference to some kind of superior experience or about the study of Buddhist doctrine rather than about the ritual and performative features of the narratives (Faure 1993, p. 225). As Faure writes, "It is significant that what may (or may not) have been at first spontaneous encounters ... eventually became a literary genre- that is, a highly ritualized form of discourse with a given sociocultural setting and specific role expectations" (Faure 1993, p. 215). The specific role expectations

5 While Schlütter notes one function of the literature was to solicit patronage from the literati (see Schlütter 2008), it also seems probable that the literature also functioned as a recruitment tactic of monastics insofar as leadership of public monasteries required many of the skills of educated literati. 
for masters and students were shaped by the rhetorical practices presented in transmission literature, and these roles are replicated in the event of reading where the "student-reader" submits to the judgment of the "master-text" rather than the other way around. Classical Chan challenges modernist subjective aesthetics where audiences use their faculty of taste to judge the work.

\subsection{Reducing Differences between Orality and Textuality}

The life of literary texts, especially those bearing a dialogical structure, parallels the performative surrounding of musical scores, a literary genre where subsequent readers interpret the texts by literally performing them. Each performance tries to get the piece correct or right. As Gadamer writes, "I am not convinced by the objection that the performance of a musical work of art is interpretation in a different sense from, say, reaching an understanding in reading a poem or looking at a painting. All performance is primarily interpretation and seeks, as such, to be correct. In this sense it, too, is 'understanding'" (Gadamer 2013, p. xxvii). According to Gadamer, the interpreter's performance of reading or co-speaking always accompanies literary texts in their life in a community (Gadamer 1989, p. 46). Both reading silently and reading aloud involve the same structure insofar as they are dialogical. When one reads a text, whether aloud or silently to oneself, one reads it for someone, which means one engages in dialogue. Just as in live dialogue, the dialogue that occurs in reading bears many marks of orality in the moment of performance. Like a guardian sounding out voices of characters as they read a child a bedtime story, readers only understand to the degree they bring the sound into harmony with the meaning as they read to themselves (see Gadamer 1989, p. 147). Instructors know when students do not quite understand a text when the student's cadence and tone misses the sonorousness of the text's meaning. What musicality is needed in reading encounter dialogues? What tones are master and student questions put? Might we discover a voice of genuine questioning in the texts?

Before turning to this, the point here is that however much weight we might want to put on a rigid duality of "orality" and "textuality," it is clear that the categories are permeable in the event of reading. When it comes to literature presenting dialogical encounters in particular, reading it primarily as oral or primarily as written reflects less the essential form of the discourse but reflects more the rhetorical moves of conflicting interpretive communities and hegemonic ideologies. Categories and genres are not purely theoretical, but are also, Faure writes, "historical artifacts that allow for the institutionalization of certain kinds of practices" and hierarchies (Faure 1993, p. 236). Whose interests are served by reading the texts one way or another? We know, just as with other religious traditions like Christianity, that certain miraculous or profound events are treated as "historical" not because they are able to be authenticated but because they serve the interests of the status quo.

In an effort to navigate between the conflict of interpretations dominated by the reification as well as the rarification of "orality" and "textuality" scholars have undertaken performative studies of discourse regardless of whether the discourse is written or spoken. As McIntyre makes clear, the conceptual backdrop of narrative unity renders an individual's actions intelligible (MacIntyre 1984). So in a fundamental sense, an individual's life must be understood as the performance of a narrative (see Ricoeur 1986). Life is not only the stage where we are the players; we players also perform a text. Just as the ambiguity in the notion of "character" divulges the difference and identity between the field of textuality and the field of orality, so also does the performative approach to discourse attend to the difference and identity of text and speech. The so-called "encounter dialogues" of classical Chan masters present a unique opportunity for undertaking such an interpretive experiment. It is to encounter dialogues themselves that I shall now turn.

\section{The Genre of Encounter Dialogues}

In this section, I delineate general characteristics of jiyuan wenda (again, "encounter dialogues") through the examination of specific examples. The depiction of these rhetorical interactions between characters are understood in modern Western scholarship to bear characteristics of illocutionary language and non sequitur responses, responses that, according to Chan self-understanding, indirectly 
manifest enlightenment (Schlütter 2008, p. 92). McRae argues that encounter dialogues represent a kind of interaction between master and student required by the genealogical structure of the Chan transmission tradition (McRae 2003, p. 97). They are, in a sense, an instance of the Chinese transformation of the Indian mārga ("spiritual path"), the individual's progression from ignorance to enlightenment (see Hershock 2009, pp. 36-37). This makes sense given the dynamically interactive cosmology and ontology presupposed in pre-Buddhist Chinese culture (see Mair 1983). Rather than the psychological journey of a solitary individual making gradual progress towards the telos of enlightenment, Chan spiritual cultivation and practice forced students into rhetorically engaged interaction. As Sharf writes, "[Chan] mārga treatises are not so much maps of inner psychic space as they are scripts for the performance of an eminently public religious drama" (Sharf 1995, p. 269). Thus, in Chan traditions, solitary spiritual progression shifts to interpersonal collaboration (McRae 2003, p. 98). We can isolate five general patterns of the collaborative intersubjectivity of Chan spiritual cultivation in encounter dialogues, patterns that can help us isolate uses of questions in particular.

First, encounter dialogues are often the context for a student's experience of awakening. Consider the following example between Mazu and Dazhu Huihai:

When Dazhu came to see the Ancestor for the first time, the Ancestor asked him, "Where are you coming from?" "I am coming from Dayun Monastery in Yuezou." replied Dazhu. The Ancestor asked him, "What is your intention in coming here?" Dazhu said, "I have come here to seek the Buddha-dharma." The Ancestor said, "Without looking at your own treasure, for what purpose are leaving your home and walking around? Here I do not have a single thing. What Buddha-dharma are you looking for?" Dazhu bowed, and asked, "What is Huihai's own treasure?" The Ancestor said, "That which is asking me right now is your own treasure- perfectly complete, it lacks nothing. You are free to use it; why are you seeking outside?" Upon hearing this, Dazhu realized the original mind without relying on knowledge and understanding. Overjoyed, he paid his respects to the Ancestor and thanked him. After this he stayed with him for six years and served him as his disciple. (Cheng Chien 1992, pp. 69-70)

The encounter dialogue above depicts Mazu soliciting realization from Dazhu, and he does so through a discursive interaction as opposed to a choke or blows with his fists. Mazu reorients Dazhu's quest for the Dharma back toward Dazhu himself, which implies that the most important "answers" to Dazhu's quest can only be realized in a self-conscious relation to the "who" of questioning (Wright 1992a, p. 45). Additionally, insofar as the interaction represents the cosmology and ontology of Chan thought, the "who" is much more than an isolated subject of experience but an improvisational jazz performance with others (see Hershock 2009, pp. 79-80).

Second, the encounter dialogues often read as spontaneous interactions and the exchange of wenda (again, "question-and-answer") appears to be pre-reflective-in that the interchange, especially the responses of the master, flows back and forth without hesitation and reflection (Wright 1993, p. 36). Indeed, "immediacy" and "directness" are some of the highest forms of praise for the rhetorical practices of masters in transmission literature. Given that according to Buddhist doctrine a master has no self and thus no premeditated intentions, Wright argues, the master's role in dialogue reflects in a selfless way whatever is manifest or can become manifest in the moment (Wright 1998, 101). Consider the following example of prereflective response on the part of Mazu's peer, Shitou:

A monk asked, "How does one get emancipated?" The Master said, "Who has ever put you in bondage?" Monk, "What is the Pure Land?" Master, "Who has ever defiled you?" Monk, "What is nirvana?" Master, "Who has ever subjected you to birth-and-death?". (quoted in Suzuki 1978, pp. 105-7)

Shitou's responses to the monk just bounce back, apparently without hesitation or reflection. This example of Shitou's agility and capacity to respond without hesitation illustrates the general 
virtuosity of masters to speak words well-suited to exposing the power of the present moment (Hershock 2009, p. 117). Hesitation or faltering as a consequence of premeditation would divulge a failure to undividedly attend to the contingencies of the situation (see Wright 1993, p. 37). In classical Chan self-understanding, the character and discourse of masters are a function of the dao rather than the premeditated acts of individuals. As Mazu claims, "The very words I now speak are nothing else but a function of the Way" (Pas 1987, p. 40).

A third characteristic closely related to the second, encounter dialogues often depict masters comporting their behavior to contingent and situation specific circumstances. Consider the following example of Dongshan interacting with a student:

One time when the master was washing his bowls, he saw two birds contending over a frog. A monk who also saw this asked, "Why does it come to that?" The Master replied, "It is only for your benefit, Āchārya.". (Foster and Shoemaker 1996, p. 122)

The contextual information referring to birds fighting over a frog, as well as the lament of the student, provides readers with knowledge of the contingent situation to which Dongshan responds. Encounter dialogues present masters as unhesitating and unflinching in the face of the central Buddhist realization of the impermanence, emptiness, and groundlessness of every contingency. As Wright characterizes such situational sensitivity of Chan masters, "The [Chan] master is the one who no longer seeks a solid ground, who realizes that all things and situations are supported, not by firm ground and solid self-nature, but rather by shifting and contingent relations" (Wright 1998, p. 100). Insofar as these characters are depicted as engaged in some form of dialogue, the meaning of their words also depends on the context, a context including not only words, but also gestures, vocal inflection, and the entire existential setting in which spoken words occur (see Faure 1993, p. 227). In essence, the thinking of the masters is depicted as situational as opposed to categorical.

Fourth, as a consequence of the conventions of the transmission literary genre, encounter dialogues arrange the characters hierarchically with regard to one another, though there are rare exceptions illustrating those instances where former students have themselves achieved mastery over Chan rhetoric or achieved enlightenment. Consider the following two examples involving Linji and two different interlocutors, where the second example represents an instance breaking the norm of hierarchy establishment while simultaneously illustrating it:

Someone asked, "What was Bodhidharma's purpose in coming from the west?" The Master said, "If he had a purpose, he wouldn't have been able to save even himself!" The questioner said, "If he had no purpose, then how did the Second Ancestor manage to get the Dharma?" The Master said, "Getting means not getting." "If it means not getting," said the questioner, "then what do you mean by 'not getting'?" The Master said, "You can't seem to stop your mind from racing around everywhere seeking something. That's why the Ancestor said, 'Hopeless fellows-using their heads to look for their heads!' You must right now turn your light around and shine it on yourselves, not go seeking somewhere else. Then you will understand that in body and mind you are no different from the Ancestors and buddhas, and that there is nothing to do. Do that and you may speak of 'getting the Dharma'". (Sasaki 2009, pp. 28, 265-66)

The Master said to Xingshan, "How about that white ox on the bare ground?" Xingshan said, "Moo, moo!" The Master said, "Lost your voice?" Xingshan said, "How about you, Reverend?" The Master said, “This beast!". (Sasaki 2009, pp. 38, 302)

On first reading, these two encounter dialogues might appear unrelated because, on the one hand, a student consults Linji, and on the other hand, a student appears to rebel against him. Whereas a student seeks doctrinal clarification from Linji in the first example, Linji-insofar as he plays the role of master-is hardly consulting Xingshan for doctrinal clarification. Yet the differences between the stories is less important than their similarity. As a result of the conventions of the genre, Linji in both cases usurps the role of commentator, judging the level of understanding of the student. In these 
kinds of interactions, the master represents the standpoint of enlightenment as heir to the lineage, and thus speaks from the position of authority. The interlocutor represents, as Foulk writes, "abject delusion, striving for awakening, or awakened insight rivaling that of the master, but is always in the inferior position of being evaluated by the voice of the master" (Foulk 2000, p. 33). Yet in the case with Xingshan, it is not clear that Linji judges Xingshan as inferior-that is, his final words on the matter do not have the same condescension as when he discourages the questioner in the first case.

Fifth, and finally, in close connection to the hierarchy established in the exchange, encounter dialogues are often agonistic or conflictual in nature. They are often referred to as "dharma battles" (Faure 1993, p. 213). The interactions between the characters exhibits the hierarchy because the interactions typically produce winners and losers. The method of the masters is often to pose an inescapable quandary and then to demand an immediate response-a game at which one can only expect to lose (see Wright 1993, p. 33). Masters pressure their students for response, a response that must be given under their judging gaze. Consider the following example involving Shitou and his student, Yueshan Weiyan:

Yueshan ... an enlightened monk, was doing [Chan meditation]. His master Shitou asked him, "What are you doing [Chan meditation] for?" Yueshan answered, "Not for anything." "That means you are sitting idly," said Shitou. Yueshan countered, "If this is sitting idly, then that would be for something." The master then said, "What is it that is not for anything?" The monk answered, "A thousand sages wouldn't know". (Sheng-yen 1988, p. 43)

Shitou is engaged here in a dharma battle with his student, posing impossible questions demanding immediate responses to be subjected to his judgment. Yet, the student appears to have succeeded in demonstrating enlightenment, however inferior, insofar as the dialogue ends without the master's judgment and commentary. The orality of these interactions situate awakening and knowledge in the context of struggle and negotiation (see Faure 1993, p. 226).

Through our survey of specific examples, we can generalize that many encounter dialogues share several features. They are often the context for enlightenment experiences, as well as the context for displaying the enlightened mind of masters. They often display characters in apparently spontaneous and pre-reflective interaction who are attentive to situational contingencies. Through the dialogue, the characters try to position themselves hierarchically. Moreover, the dialogues are often agonistic in nature. What I want to know, though, is what roles questions play in this context. I now turn to develop a performative model of questions with an aim at determining the performative character of questions in classical Chan.

\section{A Performative Approach to Questions in Encounter Dialogues}

In this section, I outline the performative approach to language developed in speech act theory, calling attention to ways this approach can apply to discursive practices in encounter dialogues. Then I narrow the scope to the phenomena of questions in particular.

\subsection{A Performative Approach to Chan Rhetoric}

In response to the positivistic reduction of language to a system of signs representing and corresponding to states of affairs in the world, and arising out Ludwig Wittgenstein's (1889-1951) later investigations of language and meaning, J.L. Austin (1911-1960) developed a theory of the performative force of utterances (see Austin 1976). The performative dimension of language draws attention to how the meaning of statements is not only a matter of what those statements refer to, but it is also a matter of what people intend to do with those statements. He distinguished between three basic kinds of speech acts: propositional (or locutionary), ${ }^{6}$ perlocutionary, and illocutionary. The most significant

6 In using "propositional" rather than "locutionary" I am subscribing to the convention of (Searle et al. 1980). 
propositional speech act is the rhetic act in which we intend to make sense and refer to things with our sounds and markings in order to transfer information (Martinich 2001, p. 124). For example, in saying "The children are on the see-saw," I intend to refer to those children on that see-saw with my words. Illocutionary speech acts are the various forces that rhetic acts carry; that is, illocution is what one intends to do along with what one says. For instance, the speech act, "Go play on the see-saw," possesses both the propositional act of referring to the see-saw and the illocutionary intention of an imperative. Perlocutionary dimensions of speech acts are those intended effects on a listener in a way that goes beyond the listener's propositional understanding of what is said (Searle et al. 1980, p. vii). For instance, when a parent threatens a child with punishment for misbehavior by saying, "Eat your peas or you cannot go out and play," the parent intends to instill some sense of fear in the child in addition to referencing peas.

The primary focus of performative studies of utterances is on illocutionary acts. According to Searle, there are five basic illocutionary acts: assertives, directives, commissives, expressives, and declaratives (Searle 1979, pp. 1-29). Assertives entail one's commitment to the truth of that which is asserted. Directives are attempts to get a listener to do something, as in commands or pleading. Commissives are those utterances whereby one commits oneself to future action. Expressives articulate feelings or psychological states as they relate to the rest of the content of what is said. Through declaratives, one attempts to bring about a correspondence between the words and the world. It is in the declarative genus that the classic example of "I do" in a wedding has its place. However, speech act theorists also place questions in the directive genus. As Searle writes, "Questions are a subclass of directives, since they are attempts by [the speaker] to get [the hearer] to answer, i.e., perform a speech act" (Searle 1979, p. 14). Are questions just commands to get someone to do something? Is this what masters are doing when they ask questions of students? Might they have perlocutionary effects as well?

Perlocutionary acts also play a significant role in the event of discourse. Perlocutionary acts are instances of language intended for ends other than the transfer of information. They involve the listener with the speaker in a crucial relationship because perlocutionary acts can fail in ways that propositional and illocutionary acts cannot (Rosemont 1970, p. 116). Illocutionary acts such as asserting or committing appear to depend solely upon the speaker's ability to assert or commit to something. An utterance such as, "I assert that," when performed in hospitable situations, is successful in that the intention is fulfilled upon completion of the utterance. However, statements such as, "I alarm you that," besides being grammatically incorrect, cannot be fulfilled without also bringing about alarm in the listener, and thus involve the listener in a critical way. As Rosemont writes, "We may often speak with the intention of convincing, consoling, alarming, or annoying someone, but such perlocutionary speech acts require a specific kind of response from our listener before they may be called successful" (Rosemont 1970, p. 116). Such speech acts situate interlocutors with regard to one another (see Wheelock 1982, p. 59). It seems that insofar as some questions masters ask facilitate sudden awakening, then perhaps a perlocutionary analysis is most fitting.

The capacity of utterances to situate dialogue partners with regard to one another derives from the figurative quality of the perlocutionary function of language (see Faure 1993, p. 149). That is, perlocutionary intentions need not directly relate to the particular words used in the speech act. For example, a guardian might speak to their child about their favorite doll in order to take their mind off an approaching dentist visit. If the goal is to alleviate worry about the dentist office, the statements need not be about dolls, but could be about almost anything. Perlocutionary acts extend beyond speech acts that merely transfer information; they are speech acts only indirectly related to the content of remarks (see Rosemont 1970, p. 117).

Just as with any other discursive practices, Chan discursive practices also bear the marks of performative language. Encounter dialogues are illocutionary in that students often express their deluded states and masters declare judgments. The rhetorical interactions are also perlocutionary, in that masters attempt to produce effects in their students. In Chan discursive practices, the "saying" is placed in a more fundamental position than the "said." The performative character of the interactions 
involve not so much the referential content, but the formal positioning between the characters where masters put students in their place. As Faure elaborates, the utterances of Chan masters are not simply propositional acts asserting truths, but are also attempts to impress those truths upon their interlocutors as well as to gain the upper hand (Faure 1993, p. 149).

The speech of Chan masters in encounter dialogues is not merely representational, but is performative insofar as it is disruptive, transgressive, and throws the compulsive grasping of students into question (Wright 1992b, p. 128). The rhetorical practices of Chan masters call into question normal states of mind through undercutting and disrupting interlocutors engrained in the posture of a grasping subject, and this evokes disorientation in the student, which Wright suggests is essential to orienting oneself (Wright 1993, pp. 31-32). Furthermore, rather than resolving things by providing definitive answers to questions, the language of Chan masters disrupts things and opens them up. In the case of the rhetorical practices of classical Chan masters, we have, as Wright points out, a religious discourse that stimulates doubt as much as belief (Wright 1993, p. 32).

\subsection{Performative Features of Questions in Chan Encounter Dialogues}

As we have seen, both Chan masters and their students are often depicted posing questions in encounter dialogues. In speech act theory, questions have clearly defined illocutionary force. And they appear to have a specific perlocutionary effect. According to speech act theorists such as Martin Bell, questions, or statements in the interrogative mood, have the illocutionary force of commands. As Bell writes,

Acts of questioning are illocutionary acts belonging to the command [or for Searle, directive] genus. They are distinguished by the nature of what is commanded [-linguistic responses], and possess their own performative verb, to ask, a verb which also doubles as merely one of the family of command verbs. (Bell 1975, p. 206)

While a question may be what is said, commanding a response is what a question purportedly does. Questions are the functional equivalent of commands in that they attempt, in Searle's words, to "get the world to match the words" (Martinich 2001, p. 152) by moving someone to do something, namely, answer. Like the shave-and-a-hair-cut knock, answering is often irresistible. Interrogatives are apparently a subclass of imperatives for speech act theory. Does this fit what we have observed with question uses in Chan encounter dialogues?

Speech act theorists take the information question (or the "yes-or-no" question) as paradigmatic and most readily available to the method of analysis employed to display illocutionary force. The method of analysis consists of transposing a given question into a set of potentially true propositions logically implied by the question. For instance, consider the question, "Would you like some tea?" Analyzing this question consists of listing out the possible propositions implied by the question-in this case, "No, I do not want some tea." and, "Yes, I would like some." Asking such a question is the illocutionary equivalent of the following command: "Affirm one of the following statements by nodding your head: 'I would like some tea.' 'I do not want tea.'" While the propositional act may be different in each case, what is performed is the same: a command. However, the key factor in determining the illocutionary force of an utterance is the status or position of the speaker relative to the hearer, such as a master to a student. However, Bell argues that a question is "authentic" only if the questioner does not know ahead of time the truth value of the possible propositions (Bell 1975, p. 207). This seems reasonable because why would one ask a question to which she already knew the answer (unless it was for rhetorical purposes, like this one)?

Interrogatives possess a peculiar structure that makes it possible for them to function as imperatives. Although preceding speech act theory by a number of decades, Heidegger's (1889-1976) work on delineating formal structures of questions supplements the speech act approach to questions. In his attempt to address the question of the meaning of being, Heidegger found it necessary to delineate the formal structure of questions and he isolated four formal elements. With regard to the first formal 
element, Heidegger writes, "Every questioning is a seeking" (Heidegger 1996, p. 3). As a mode of Dasein, questioning aims in the direction taken "from what is sought." This implies the questioner already has a vague sense of it. How can we ask a question about something of which we are completely clueless? The second formal element is this intended object of which one has a vague grasp. The third formal element is the interrogated object, the one to whom we address our question (Heidegger 1996, p. 4). In one sense, the interrogated object contains the answer because we receive our answer from it; in another sense, it functions as a medium for the clarification of the answer we already possess. Recall Mazu's question to Dazhu — why are you seeking outside? The fourth formal element is the theoretical gain, or clarification, which results from one's questioning. According to Heidegger, interrogative activity is a mode of the fundamental anxiety and apprehension of existing in the face of finitude and disorientation. Compelled by anxiety, we act; but we can only do so authentically through resolve, partly attained through negating indeterminacy polluting our experience. Thus, characterized in another way, questions are a means for attaining re-solve by dis-solving the impurity contaminating the intended object in the solution of the interrogated object. It matters little who or what the interrogated object is, except to the degree that it functions as a means for decontaminating the intended object. Thus, Heidegger's model of the structure of questions exhibits their perlocutionary consequence: questions intend to dispose the interrogated object toward providing answers. In other words, questions intend the subjection and obedience of the listener to the questioner's command for answers. Judith Butler argues that this is precisely why we find answering questions so irresistible: subjection offers a form of identity (see Butler 1997).

As the above analyses show, the performative character of so-called "authentic" question-acts involves two intentions: on the illocutionary level, questions intend to command an answer; and on the perlocutionary level, questions intend the listener be disposed to answering. Returning to Chan encounter dialogue literature, do any of the masters' or students' questions bear the marks of the performative features of authentic interrogatives? Recall that, as textual beings, it is not possible to uncover the real intentions of masters and students as historical persons. Nevertheless, we can safely assume that those questions bearing the features of interrogatives divulge the fictional character's intentions, a construct produced by means of the genre's conventions. Students often appear to perform authentic interrogatives, and to presuppose that all syntactically correct interrogative statements have cognitively significant answers (see Rosemont 1970, p. 119). The monk engaged with Shitou, cited above, appears to pose an authentic interrogative in asking, "How does one get emancipated?" And the rapid series of questions that follows seems to disclose the student's anxiety, the anxiety that accompanies all authentic questioning. When the student asks Linji to define what he means by "not getting" after subjecting him to an earlier series of interrogations, we see what appears to be another example of an authentic interrogative. It seems reasonable to generalize from these examples that the performative character of student questions are typically—however much the students ultimately fail to attain the intended results-authentically interrogative. Not all student questions are authentic, though. The student depicted in an episode with Dongshan, for instance, appears more to lament over the birds vying for a frog than to pose an authentic interrogative. And in the dharma battle between Linji and Xingshan, Xingshan's question appears to one-up Linji by turning Linji's pedagogical question back around on him.

In contradistinction to typical performative practices of students, masters rarely appear to pose authentic interrogatives, if they ever do. This is an apparent consequence of how the role of master is constructed according to conventions of the encounter dialogue genre. Not only is the master positioned in the role of judge, each master is also understood to be an heir to the same enlightenment as Shakyamuni Buddha. Insofar as masters are presented as thus enlightened and capable of issuing judgment, as well as omniscient in the sense of knowledge of all past and future karma, then it seems that masters are incapable of posing authentic interrogatives. In the example where Shitou confronts Yueshan, Shitou poses the challenge, "What are you doing [Chan meditation] for?" The narrative's presentation of Shitou's enlightened mind mitigates against interpreting this question as an authentic 
interrogative. How can someone with all the answers ask an authentic question? In another example, at a critical moment in the exchange, Mazu poses the question to Dazhu, "You are free to use it; why are you seeking outside?" Insofar as Mazu is presented as already knowing everything about Dazhu, then Mazu cannot be read here as posing an authentic interrogative. This is not to say, however, that Mazu's reflexive question is not effective for helping Dazhu realize the Dharma. At any rate, it seems reasonable to generalize from these examples to the principle that the performative character of questions imposed by masters is typically not authentically interrogative. Masters do not use questions as questions.

Employing the performative approach to questions in the interpretation of master and student questions leads us to the general conclusion that while students often pose authentic interrogatives, masters rarely do. The authentic interrogatives of students, though, often fail to fulfill their intentions. On the dramatic level, this is due to the disruptive tactics of Chan masters. On the level of the conventions of the genre that positions masters hierarchically in relation to their students, it is impossible for students to successfully pose questions insofar as questions are the illocutionary equivalent of commands and have the perlocutionary consequence of subjecting the listener. A student cannot in principle subject a master. A basic principle of the genre appears to be that masters are characters who can neither be commanded by, nor subjected to, the intentions of other characters in the drama.

However, there are good reasons for doubting the adequacy of speech act and Heideggerian performative characterization of questions. ${ }^{7}$ First, contrary to presuppositions of speech act and Heideggerian approaches to questions, Chan rhetorical practices do not imply a self-controlled agent with intentions (see Faure 1993, p. 213, note 22). Chan masters must be understood as realizing the Buddhist truth that there is ultimately no self that would function as the locus of intentions. If we are going to take Chan self-understanding seriously, then it entails attempting to understand the characters in Chan encounter dialogue as acting and speaking without a centered subject capable of intentions.

Second, and closely connected to the first, the master and student are ultimately the same given the thesis of inherent enlightenment to which Chan traditions subscribe. So the only difference between the master and the student from the perspective of Chan traditions is that the students have not realized their enlightenment. That is, the distinction is a matter of the student perspective, not the master perspective. Or, it is a matter of the reader perspective, not the text's perspective. From the master's point of view, the student has just as much to "offer" the encounter (see Hershock 2009). The perpetuation of this difference between masters and students in Chan encounter dialogue is a consequence of the fact that primarily students were the ones collecting the stories and editing the transmission narratives. ${ }^{8}$ The conventions of the genre are a construction of the student perspective and lead the reader to see things from the student perspective.

Third, just as with Chan masters attuned to the moment, so also does "dialogue" in the modern sense require attentiveness to contextual contingencies. In other words, reaching an understanding through dialogue requires we comport our behavior toward alignment with the dramatic and textual flow of the interchange. The speech act and Heideggerian analyses artificially isolate questions from their practical contexts. Questions do not occur in conversational outer space. They are often nothing extraordinary; indeed just asking another person questions is one of the most ordinary things humans do. Questions often form part of the give-and-take playfulness of dialogue. And if the exchange is such a dialogue, then the exchange of questions is guided by the movement of the moment and subject matter, not the intentionality of the seeker. Questions, like ideas, occur to us, and in very real sense are more a passion than an action (see Gadamer 2013, p. 379).

7 This may feel anticlimactic. Fish, for example, notes that speech act theory only provides trivial information about texts when used as a hermeneutic (see Fish 1976).

8 I would like to thank the late Matthew Wilhite for bringing this diagnosis to my attention. In conversation, April 30, 2007. 
Fourth, interrogation, and its implicit anxiety, renders us so obsessed with getting "the" answer that we neglect realizing the communion of reaching an understanding. In interrogation, the spontaneity and uniqueness of the interrogated object cannot play an essential role. Authentic questions so heavily predetermine the answer that, in a technical sense, an interrogative question is not so much posed but imposed (see Fenves 1993, p. 21). For instance, when I ask, "Where are my keys?" it matters little who tells me the truth, namely, "They are locked in your car." The other is here reduced to a mere means for my ends, and so even if the transference of information about keys is successful, this particular discursive event fails to be a dialogue.

Therefore, it is important we construct an alternative model of questions that pays sufficient attention to Buddhist self-understanding and corresponds to our contemporary ideas about dialogue. I wager that open questions provide leverage for construction of an alternative because the force of interrogation is implicit in all questions except open or "genuine" questions (see Dickman 2018). Genuine questions are often used to conclude lectures, such as when a lecturer says, "What is the meaning of life?" These kinds of questions, according to speech act theorists, are spoken as if in quotation marks and hence "no illocutionary force attaches to [them]" (Bell 1975, p. 209). In essence, speech act and Heidegger marginalize genuine questions. I propose we conceive of genuine questions as discourse that carries not the force of a speech-act but the receptivity of listening. Indeed, these questions are a way in which we listen with our mouths. This mode of listening by asking open questions is one of the most mundane things we do in ordinary and passing conversations. This is crucial to emphasize since Mazu teaches that "ordinary mind is the way" (see Poceski 2007). Such open questions represent what I call genuine questions, and while they preserve some of the elements of speech act and Heideggerian analyses of questions, they replace interrogative anxiety with playful and invitational enthusiasm, in the archaic sense of the word, as "spirit possession" or "god inspired." I conclude here by defining genuine questions and reflecting on the possibility of the occurrence of them in Chan encounter dialogues. I provide this as a suggestive speculation rather than an assertion that genuine questions definitely occur in encounter dialogues.

\section{Genuine Questions: An Unexplored Possibility}

Genuine questions are necessary for dialogues aimed at reaching an understanding with others. There appear to be at least four criteria a question must meet for it to be genuine. First, as we learned from the speech act development of authentic interrogatives, the questioner cannot know the answer; whatever is at issue must as of yet be unresolved. Second, as we learned from Heidegger, the questioner must desire to know the answer; there must be some kind of quest or seeking for a resolution. However, the seeking in genuine questions is not a function of anxiety, but is rather the articulation of a surplus of sensitivity to the contingencies of the situation. Third, rather than methodically interrogating the other through commands, the question must be invitational; like the vulnerability and openness of our ears, it must be open to the participation of others, the guidance of the subject matter under discussion, and the contingencies of the moment. ${ }^{9}$ And finally, the question must invite others into further dialogue about a subject matter insofar as questions occur within the give-and-take of dialogue.

Do any of the Chan masters or students depicted in encounter dialogues pose genuine questions? Do the conventions of the genre mitigate against this possibility? This interpretive endeavor appears to have been neglected in Western scholarship to interpret encounter dialogues. Just asking genuine questions is one of the most ordinary activities humans engage in. Indeed, insofar as religions and sacred writings in particular are considered to be answers to the human predicament, then just asking around with others is also one of our most profane activities (see Tillich 1951).

9 One might wonder just what makes invitation open as opposed to interrogation. This is, in effect, a result of our ability to critique our presuppositions. In literal terms, in order to invite another to an event, we must first make room for them. In terms of performative force, invitation is primarily something we do to ourselves and only secondarily something we do to another. 
We can consider this speculation a live interpretive possibility on a couple grounds. Hu Shih, in his polemic against D.T. Suzuki's psychologization of Zen, points to the first ground by stressing the plain and profane character of the masters' words (Hu 1953, p. 20). As Hu writes, "All authentic documents of that period show that the great masters ... taught and spoke in plain and unmistakable language and did not resort to enigmatic words, gestures, or acts" (Hu 1953, p. 20). He cites one of Mazu's heirs, Xuanjian, who taught the doctrine of "doing nothing" and whose advice was,

[to] take a rest and have nothing to do ... Put on your clothes, eat your food, and move your bowels. That's all. No life-and-death to fear. No transmigration to dread. No nirvāna to achieve, and no bodhi to acquire. Just try to be an ordinary human being, having nothing to do. (Hu 1953, p. 18)

If masters ought to be interpreted as thus attuned to the ordinary, then it may be possible that some of their questions are genuine. What is more ordinary, and therefore more profane, than just asking some questions with no particular direction in mind except to listen?

We can glean an additional ground on which it seems possible to interpret masters' questions as genuine in Wumen Huikai's Gateless Barrier, a medieval gongan collection with commentary. In Wumen's hermeneutic, the reader is not to take a master's words symbolically because the words are "perfectly clear" (see Foulk 2000, p. 40). The symbolic interpretation is a clear indication of a deluded mind, according to Wumen. The conventions of the genre seem designed to lead the reader to interpret the masters' words symbolically, just as the conventions seem designed to lead the readers to interpret their questions as rhetorical strategies to solicit awakening. Yet if we interpret masters' questions solely as rhetorical strategies aimed at awakening students, rather than interpreting them as genuine, then we may be just as deluded as the readers who are tempted to interpret the masters' words symbolically.

Asking genuine questions, however, is primarily an oral phenomena. So reading encounter dialogues with a sensitivity for identifying genuine questions requires reading them in a certain tone of voice. As Gadamer writes, "Even the simple act of reading in which one reads something to oneself is dialogical, in that in it one must bring the sound and the meaning as much as possible into harmony" (Gadamer 1989, p. 47 my emphasis). If we can discover the tone of voice of genuine questioning in the text, then we ought to be able to disclose something about the meaning of encounter dialogues as well as the character of masters and students. Like the students, readers pose their own authentic interrogatives to the literature and have those intentions disrupted in the dialogical practice of reading. Yet within the practice of reading, some change of mind and character occurs through an exchange of questions. As Wright puts the matter,

Reading critically, we question what is said in the text; reading reflexively, we allow what is said in the text to question us. For every statement made in the text, an important question probes the reflexive reader: what do you think? A unilateral reading, which seeks only to absorb what the author has said, casts no light back upon the reader. (Wright 1998, xiii)

While students (and, to some extent, readers) unilaterally pursue the fulfillment of their intentions, masters call those very efforts into question (see Rosemont 1970, p. 118). However, if masters do pose genuine questions once in a while, then this might have a transformative effect on the reader's self-understanding.

Given the plain character of the masters' discursive practices, and given the inappropriateness of interpreting their words symbolically, it seems possible at times to interpret the masters' questions as genuine. Insofar as just asking around is an ordinary and profane practice, or even irreverent, then Mazu's question, "Why are you seeking outside?" might just be genuine.

Acknowledgments: I would like to thank Morten Schlütter and Matthew Wilhite for feedback on previous drafts of this manuscript, as well as thank the audience for their feedback to a presentation of it at the Upper Midwest regional meeting of the American Academy of Religion in 2009. I also want to thank two reviewers for their critical and constructive feedback. And I thank Macy Zong and the team at Religions for their work to help in getting this article ready. 
Conflicts of Interest: The author declares no conflict of interest.

\section{References}

Anderson, Pamela Sue. 2001. Gender and the Infinite: On the Aspiration to Be All There Is. International Journal for Philosophy of Religion 50: 191-212. [CrossRef]

Austin, J. L. 1976. How to Do Things with Words, 2nd ed. Edited by James Opie Urmson and Marina Sbisá. Oxford: Oxford University Press.

Bell, Martin. 1975. Questioning. The Philosophical Quarterly 25: 193-212. [CrossRef]

Berling, Judith A. 1987. Bringing the Buddha Down to Earth: Notes on the Emergence of 'Yu-Lu' as a Buddhist Genre. History of Religions 27: 56-88. [CrossRef]

Butler, Judith. 1997. Conscience Doth Make Subjects of Us All: Althusser's Subjection. In The Psychic Life of Power: Theories in Subjection. Stanford: Stanford University Press.

Cheng Chien Bhikshu (i.e., Mario Poceski). 1992. Sun Face Buddha: The Teaching of Ma-tsu and the Hung-chou School of Chan. Berkeley: Asian Humanities Press.

Dickman, Nathan Eric. 2018. Hermeneutic Priority and Phenomenological Indeterminacy of Questioning. In The Significance of Indeterminacy: Perspectives from Asian and Continental Philosophy. Edited by Robert H. Scott and Gregory S. Moss. New York: Routledge.

Faure, Bernard. 1986. Bodhidharma as Textual and Religious Paradigm. History of Religions 25: 187-98. [CrossRef] Faure, Bernard. 1993. Chan Insights and Oversights: An Epistemological Critique of the Chan Tradition. Princeton: Princeton University Press.

Fenves, Peter. 1993. "Chatter": Language and History in Kierkegaard. Stanford: Stanford University Press.

Fish, Stanley. 1976. How to do Things with Austin and Searle: Speech Act Theory and Literary Criticism. MLN 91: 1024-25. [CrossRef]

Foster, Nelson, and Jack Shoemaker, eds. 1996. The Roaring Stream: A New Zen Reader, 1st ed. Hopewell: The Ecco Press.

Foulk, T. Griffith. 2000. The Form and Function of koan Literature: A Historical Overview. In Kōan:Texts and Contexts in Zen Buddhism. Edited by Steven Heine and Dale S. Wright. New York: Oxford University Press.

Gadamer, Hans-Georg. 1989. Text and Interpretation. In Dialogue \& Deconstruction: The Gadamer-Derrida Encounter. Edited by Diane Michelfelder and Rchard Palmer. Albany: SUNY Press.

Gadamer, Hans-Georg. 2013. Truth and Method, 2nd revised ed. Translated by Joel Weinshimer, and Donald G. Marshall. New York: Bloomsbury.

Heidegger, Martin. 1996. Being and Time. Translated by Joan Stambaugh. Albany: SUNY Press.

Hershock, Peter. 2009. Chan Buddhism. New York: Oxford University Press.

Hu, Shih. 1953. Ch'an (Zen) Buddhism in China: Its History and Method. Philosophy East and West 3: 3-24.

Hui Hai. 2015. The Zen Teaching of Hui Hai on Sudden Illumination: Being the Teaching of the Zen Master Hui Hai, known as the Great Pearl. Translated by John Blofeld. London: Buddhist Publishing Group.

Jia, Jinhua. 2006. The Hongzhou School of Chan Buddhism in Eighth- through Tenth-Century China. Albany: SUNY Press. MacIntyre, Alasdair. 1984. After Virtue, 2nd ed. Notre Dame: University of Notre Dame Press.

Mair, Victor H. 1983. The Narrative Revolution in Chinese Literature: Ontological Presuppositions. Chinese Literature: Essays, Articles, Reviews (CLEAR) 5: 1-27. [CrossRef]

Martinich, A. 2001. Speech Acts. In The Philosophy of Language, 4th ed. Oxford: Oxford University Press.

McRae, John R. 2003. Seeing Through Zen: Encounter, Transformation, and Genealogy in Chinese Chan Buddhism. Berkeley: University of California Press.

Pas, Julian F., trans. 1987, The Recorded Sayings of Ma-tsu. Lewiston, ME: Edwin Mellen.

Poceski, Mario. 2007. Ordinary Mind is the Way: The Hongzhou School and the Growth of Chan Buddhism. New York: Oxford University Press.

Ricoeur, Paul. 1976. Interpretation Theory: Discourse and the Surplus of Meaning. Fort Worth: Texas Christian University Press.

Ricoeur, Paul. 1986. Life: A Story in Search of a Narrator. In Facts and Values: Philosophical Reflections from Western and Non-Western Perspectives. Edited by Marinus C. Doeser and John N. Kraay. Dordrecht: Martinus Nijhoff Publishers. 
Rosemont, Henry, Jr. 1970. The Meaning is the Use: Kōan and Mondō as Linguistic Tools of the Zen Masters. Philosophy East and West 20: 109-19. [CrossRef]

Sasaki, Ruth Fuller. 2009. The Record of Linji. Edited by Thomas Yuho Kircher. Honolulu: University of Hawaii Press.

Schlütter, Morten. 1999. Silent Illumination, Kung-an Introspection, and the Competition for Lay Patronage in Sung-Dynasty Ch'an. In Buddhism in the Sung. Edited by Peter N. Gregory and Daniel Getz. Honolulu: Hawai'i University Press.

Schlütter, Morten. 2000. 'Before the Empty Eon' versus 'A Dog Has No Buddha-Nature': Kung-an Use in the Ts'ao-tung Tradition and Ta-hui's Kung-an Introspection Ch'an. In Kōan: Texts and Contexts in Zen Buddhism. Edited by Steven Heine and Dale S. Wright. New York: Oxford University Press.

Schlütter, Morten. 2008. How Zen Became Zen: The Dispute Over Enlightenment and the Formation of Chan Buddhism in Song Dynasty China. Honolulu: University of Hawai'i Press.

Searle, John. 1979. Expression and Meaning. Cambridge: Cambridge University Press.

Searle, John, F. Kiefer, and M. Bierwisch, eds. 1980. Speech Act Theory and Pragmatics. Hingham: Kluwer Boston Inc.

Sharf, Robert. 1995. Buddhist Modernism and the Rhetoric of Meditative Experience. Numen 42: $228-83$. [CrossRef]

Sheng-yen. 1988. Zen Meditation. In Zen: Tradition and Transmission. Edited by Kenneth Kraft. New York: Grove Press.

Suzuki, D. T. 1978. Manual of Zen Buddhism. New York: Grove Press.

Tillich, Paul. 1951. Systematic Theology, Vol. I. Chicago: Chicago University Press.

Wheelock, Wade T. 1982. The Problem of Ritual Language: From Information to Situation. The Journal of the American Academy of Religion 50: 49-71. [CrossRef]

Wright, Dale S. 1992a. Historical Understanding: The Ch'an Buddhist Transmission Narratives and Modern Historiography. History and Theory 31: 1. [CrossRef]

Wright, Dale S. 1992b. Rethinking Transcendence: The Role of Language in Zen Experience. Philosophy East and West 42: 113-38. [CrossRef]

Wright, Dale S. 1993. The Discourse of Awakening: Rhetorical Practice in Classical Ch'an Buddhism. Journal of the American Academy of Religion 61: 23-40. [CrossRef]

Wright, Dale S. 1998. Philosophical Meditations on Zen Buddhism. Cambridge: Cambridge University Press.

Yanagida, Seian. 1983. The Development of the 'Recorded Sayings' Texts of the Chinese Ch'an School. Translated by John R. McRae. In Early Ch'an in China and Tibet. Edited by Lewis Lancaster and Whalen Lai. Berkeley: Lancaster-Miller Press.

(C) 2020 by the author. Licensee MDPI, Basel, Switzerland. This article is an open access article distributed under the terms and conditions of the Creative Commons Attribution (CC BY) license (http://creativecommons.org/licenses/by/4.0/). 